Mykhailo Kravchenko,

Doctor of Technical Sciences, Professor Kyiv National University of Trade and Economics, Kyiv, Ukraine ORCID: 0000-0002-0093-2786

ResearcherID: N-4678-2016

Dina Fedorova,

Doctor of Technical Sciences, Professor Kyiv National University of Trade and Economics, Kyiv, Ukraine ORCID: 0000-0002-9443-2941

ResearcherID: N-4553-2016

Myroslava Perepylytsya, Candidate of Technical Sciences, Associate Professor, Kyiv National University of Trade and Economics, Kyiv, Ukraine ORCID: 0000-0002-0390-0720

ResearcherID: N-3545-2016

\title{
NATIONAL CULINARY AUTHENTICITY OF UKRAINE AS THE PROPERTY OF THE NATION
}

The article is dedicated to the research of peculiarities of culinary authenticity of the Ukrainian national cuisine, caused by historical and ethnographic factors within the framework of the desk-research the analysis of general history and features of technology of the Ukrainian national cuisine was done.

Keywords: Ukrainian cuisine, culinary authenticity, ancient traditions, country's culture, national dishes

\section{Relevance of research topic.}

Traditional Ukrainian cuisine is an integral part of the country's culture and a symbol of the hospitality of its residents. Formed over centuries, and absorbing culinary traditions of various peoples, Ukrainian cuisine turned into one of the richest and the most diverse of Slavic cuisines. Many of the dishes - simple, yet exquisite have distinguished themselves with their amazing taste and gained international fame across the world.

As its reputation as «the breadbasket of Europe» suggests, Ukraine has always had a strong agricultural economy. The breeding of hardy livestock and poultry also has great significance in the Ukrainian way of life. This, coupled with the unusual richness of the soil, creates agricultural commerce worthy of admiration worldwide. 
Even today family farms in Ukraine often produce more than enough fresh fruit and vegetables, so any extra is made available at farmer's markets in even the smallest of villages. The constraints of modern life have brought about change, but Ukrainians are still prepared to faithfully pursue the freshest and most healthy products that form the cornerstone of Ukrainian cuisine.

Ukrainians, whether at home in Ukraine or abroad, believe that food is wedded heart and soul to the land, to the homestead and its ancient traditions. Cooking is an art that evolves from raw materials that must be respected, nurtured, prepared, and then shared. Many more aged Ukrainian housewives (especially in the country side) used their familiar recipes to remember people at home, in the «Old Country», to remind them of who they were and to keep in touch with their cultural identity. Many of us were learned to love of cooking and entertaining through our beloved grandmother and we love many her special Ukrainian dishes such as Nalysnyky with meat stuffings or homemade cheese, Paska and pyrizhky, potato pancakes - deruny or Kholodets - cold snack is made of meat gelatin. So many lovely Ukrainian dishes, so many warmly memories.

Ukrainian cuisine is recognized as one of the best in the world. Borscht, bacon, dumplings, dumplings and other is now on the list of the most delicious world dishes than the rich Ukrainian national cuisine. Tourists across the Earth voted for it. Ukrainian dishes ranked 8th, just between the culinary richness of Japan and China. Numerous modern ratings (Ukraine does not go out of ten of the most striking and recognized cuisines) are confirmed by mass development of the network of Ukrainian restaurants abroad: «Kyiv» - in Kyoto, Tokyo, Toronto, Singapore, Tel Aviv; «Ukraine» - in Chicago, New York, Berlin, Osnabruck (Germany); «Resto Ukraine» Paris, France; «Borshtch 'n' Tears» - in London, UK; Salo - Shanghai, China; «Ivan the Kozak» - in Hong Kong, «Ukrainskyi smak» - in Crakow; «Borsch» - in Vilnius Lithuania and others.

Analysis of the traditions of folk cooking has not lost its relevance. Seeking to diversify the restaurant products, make it more original and attractive for customs, professionals and chefs increasingly turn to the best that has already been created by Ukrainians and enrich ancient traditions with a modern culinary culture.

\section{Formulation of the problem.}

Almost all the capitals of European countries have several Ukrainian restaurants. Not only the Ukrainian Diaspora, but also local residents go «to eat borsch and to taste varenyky». Many world-famous resorts are actively developing the «Ukrainian» theme in the concept of their food. The fame of the borsch, dumplings, home sausage, cabbage rolls and other goodies of Ukraine cuisine went beyond the borders of our country and has become truly global by making a contribution to the treasury of the overall image of Ukraine as a state. That is why we have set a goal to write an article that will pay homage to the national cuisine of the country where we were born, work and live; will pay attention to the peculiarities of its culinary 
authenticity and analysis of general history and features of technology of the Ukrainian national cuisine. Through the analysis of historical and ethnographic foundations of Ukrainian folk cuisine, it is possible to search for new ideas, both technological and marketing. Study of the nature of national culinary authenticity makes it possible to preserve old recipes and use them with modern raw ingredients.

\section{Analysis of recent researches and publications.}

The information base of the research was the works of national scientists Artiukh, L. F., Albemas, N. V., Dotsiak, V. S., Bezusenko, L. M., Shalyminov, O. V., Karpenko, Iu. M., Kylymnyk, S., Kyrchiv, R. F. et al. on the problems of ethnography, features of technology of Ukrainian national cuisine.

\section{Presenting main material}

The purpose of the article is to highlight the peculiarities of the culinary authenticity of the technology of production of Ukrainian national cuisine dishes, due to the historical and ethnographic determinants.

It is important to review some of the country's history, for Ukraine history has written her recipes. Ukrainian gastronomic culture had a thorny road which reflected the history of the country itself. Territorial belongings of the Ukrainian lands to different states and empires (in different times - from the Great Duchy of Lithuania and the Polish-Lithuanian Commonwealth to Crimean Khanate, and Ottoman, Russian and Austro-Hungarian empires) led to the fact that Ukrainian cuisine had significant influences from different gastronomic cultures but still preserved its originality. The Ukraine territory became the crossing road connecting Arabia, Europe, and Asia. Located at the crossroads of the most powerful trade routes from East to West and from North to South, Ukraine was an important center of the international trade and therefore had an access to the European and the Middle Eastern products and knowledge on how to work with them. At the same time, Ukrainian lands they were a source of interesting and sometimes quite unique products. The Black Sea on the South, the Carpathian Mountains on the West, vast steppes and forests, climatic zones - from subtropical to temperate continental - provide the existence of the incredible number of edible plants, animals and mushrooms that are worthy of attention.

Ukrainian cuisine is varied and rich in taste and nutritional culinary authentically. Since ancient times Ukrainians have practiced a settled form of life based on farming. Archeological evidence shows that wheat, barley, and millet were grown in Ukraine 3,000 years ago. The earliest known farmers in the Ukraine were the Trypillians (4500-2000 B. C.). The territory of the Ukraine had rich soil and a favorable climate perfect for cultivating crops. The Trypillians grew barley, millet, rye, and wheat. They also herded sheep, pigs, and cattle. Wheat was plentiful, and soon trading routes were established along Ukraine's Black Sea coast to market the grain. Rye was introduced about 2,000 years ago, and then buckwheat was imported from Asia in the 11th century AD. Already at that time cattle, sheep, hogs, and poultry 
were raised. Beekeeping, hunting, and fishing were practiced. The exceptional fertility of Ukraine's soil and its climate were favorable to the development of agriculture, which had a marked influence on the type of food eaten by Ukrainians.

It is evident from the chronicles and other sources that even in Kyivan Rus' food was choice, varied, and plentiful. There were professional cooks at princely courts and monasteries, and in the homes of wealthy families. Also, in the Cossack period, the officers (see Cossack starshyna), settled Cossacks, and well-to-do peasants enjoyed various delicacies. In the 19th and early 20th century the culinary arts reached a high level of development, particularly in the homesteads and in the households of parish priests and the urban intelligentsia. Choice dishes were served primarily during the entertainment of guests. In time the new culinary art spread even to the villages. In general, Ukrainian cuisine does not differ from that of Western Europe, yet it has some distinctive features of its own.

As a result of Ukraine's trade relations with other countries, the cultivation of new plants, particularly from eastern and central Asia (eg, melons and eggplants), was introduced into Ukraine. The potato reached Ukraine from America through Europe in the 17th century, followed by corn, tomatoes, pumpkins, beans, cayenne peppers, cocoa, and other plants. The introduction of these new products greatly enriched the variety of Ukrainian foods.

Since ancient times bread has held a special, primary position in the cuisine of the Ukrainian people. Long ago the grain for flour was ground manually between two rounded grindstones; such querns were still in use in some places even in recent times. Then, beginning in the 13th century, water mills and windmills appeared. Today flour milling is highly developed.

A single grinding produces whole-wheat flour, which retains all the constituents of wheat and is used in baking whole-wheat bread. As milling technology was improved, white flour was produced by repeated grinding and sifting. This type of flour is used in baking white-bread or light-rye bread. In preparing rye bread the leavening agent used is not yeast but a sourdough starter, which gives the product a more sour taste than that of wheat bread. In general sour rye bread is the common type of bread produced in Ukraine, except in the southern and southeastern regions, where white-wheat bread is more common. Besides ordinary bread Ukrainians bake various ritual breads from special doughs: the braided bread (kalach), Easter bread (paska), bread with a filling (knysh), wedding bread (korovai), sweet bread (babka), and egg bread (bulka). Many kinds of pastries are popular: turnovers, doughnuts, strudel, poppy-seed rolls, sweet buns, tortes, layered coffee cakes, honey cake, rolls, and cookies. Ukrainian bread with its many variations has become quite famous.

For the common people bread was an object of reverence; it was considered holy and a gift of God. This is attested by the word for grain - zbizhzhia - meaning the totality of divinity. As a sacred object bread plays an important role in all Ukrainian folk customs. No significant family event can take place without it. Bread is used to 
bring divine blessings to the commencement of every farm task, the marriage ceremony, the birth of a child, and the move to a new home. Bread is also used at funerals and wakes to part with the dead (see Burial rites). As a sign of hospitality, guests of honor at celebrations and public functions are greeted with a ceremonial offering of bread and salt. In the past even the preparation of the dough and the baking of the bread had their own ritual practices and were performed as mysterious, almost magical, acts. Today these rituals have lost their meaning but have been preserved in the folk tradition.

The ritual breads for Christmas, Easter, weddings, and funerals have their special names, shapes, recipes, symbolic meaning, and use. The Easter bread, which is brought to church to be blessed, is in Western Ukraine of low cylindrical shape and is decorated with dough ornaments, as is the sweet bread (babka), while in eastern Ukraine paska has a tall cylindrical form. Special dough is used for the babka, which is made with milk, butter, eggs, sugar, raisins, and, for flavoring, traces of saffron, vanilla, and lemon peel. Cheesecake, layered coffee cake, dainties (khrusty), tortes, and cookies are also prepared for the Easter festivities. The main ritual wedding bread (korovai) is made of special, rich dough like that used for the babka. The korovai has a circular form and is intricately decorated with dough. There are also other kinds of wedding breads - dyven, lezhen, shyshky. There are various symbols, beliefs, and rituals, at one time strictly adhered to, connected with the korovai. For Christmas and for funerals Ukrainians bake the kalach, symbolizing eternity. For Sundays, feast days, or family celebrations they bake pyrohy (pies) made of leavened dough, or the smaller pyrizhky, a Ukrainian specialty filled with cheese, meat, cabbage, peas, buckwheat, mushroom, plum, or poppy seed. In the past beggars at church doors were given pyrohy or knyshi to pray for the souls of the dead. For Maccabees' Feast (14 August) and Transfiguration (19 August) special biscuits (korzhi) called shulyky were prepared and were served with honey and poppy seed. On the Eve of Epiphany (Shchedryi Vechir) the carolers (see Carols) were rewarded with pastries (balabushky) or pancakes (oladky). Other fancy baked goods include poppy-seed rolls, doughnuts, crescents, tortes, honey cakes, strudels (adopted from Austria), dainties, and cookies.

Cooked or baked cereal - whether wheat, barley, buckwheat, millet, oat, or corn grits - is an ancient Ukrainian food. The most commonly eaten cereals are buckwheat (kasha), millet, and, in the Hutsul region and Transcarpathia, cornmeal (mamalyga or kulesha). The same grits boiled in water or milk to produce a thin gruel is called iushka; a thicker gruel of millet is called kulish or lemishka. In recent times rice has been added to the list of cooked cereals.

There are also dishes made of dough: zatyrka (pieces of dough dropped into boiling water or milk) and dumplings (halushky) made of wheat, buckwheat, or corn flour with or without the addition of potatoes or cheese. The favorite dish made of flour is filled dumplings (varenyky) with various types of filling: cheese, potato and cheese, cabbage, meat, fish, buckwheat, plum. A quick dish, varenytsi, made of rolled 
out dough cut into triangles, is also quite popular. Such dishes as halushky, varenyky, and varenytsi are served with fried bacon, fried onions, or sour cream. Noodles, made of egg dough, are also frequently used, served either with soup or separately with cheese. Some very old foods made of flour are kvasha (a sweet dish made of fermented buckwheat or rye flour), lemishka (a thick buckwheat gruel), and salamakha (a thin gruel of buckwheat or rye flour boiled in water). Salamakha and millet grits were the main dishes of the Zaporozhian Cossacks.

The potato is the most widely used vegetable in Ukrainian cooking. It is a necessary ingredient in all soups, particularly borsch and cabbage soup. Boiled or baked potatoes are served alone or with meat, fish, cheese, cabbage, mushrooms, and so on. Potato pancakes are served with cheese or sour cream. Certain dumplings and various types of filling for varenyky and pyrizhky are made with potatoes. Another important vegetable in Ukrainian cooking is cabbage, particularly sauerkraut, which is used to make cabbage soup (kapusniak) or is served with meat, pea puree, or potatoes. Cabbage filling for varenyky and pyrizhky is also very popular. Fresh cabbage leaves or sauerkraut is used in making cabbage rolls (holubtsi), which are filled with buckwheat or millet grits, rice, or meat. In the Hutsul region and Bukovyna, holubtsi are made of raised yeast dough and are baked in sour cream. Other vegetables such as onions, garlic, carrots, turnips, radishes, and cucumbers are frequently eaten raw. Sunflower and pumpkin seeds are usually roasted. Cucumbers, cabbage (whole or sliced), tomatoes, and beet kvas (for borsch) are preserved for the winter.

Quite popular are dishes of pea or bean purees, seasoned with garlic or fried bacon. A similar dish made with oil instead of bacon is served during the Christmas Eve supper. Tomatoes are used as cold appetizers in sauces and as an ingredient in borsch. In recent times the eggplant has been cultivated in Ukraine. It is used in the preparation of ikra, a cold appetizer, or is served hot, fried, or stuffed. Mushrooms boletus, meadow mushrooms, honey mushrooms, chanterelles, milk fungi - are an essential ingredient in many dishes. Certain varieties of the mushroom (boleti, meadow mushrooms) are dried for winter; others (milk fungi and honey mushrooms) are marinated or pickled.

In the Ukrainian tradition a soup or borsch must be served with dinner. Various soups - made with meat, fish, vegetables, fruit, or milk-are popular, but borsch remains the favorite. It is made of vegetables, among which beets and cabbage are predominant, and meat or fish stock. There is also a meatless (Christmas) borsch consisting of various vegetables cooked in water and soured with beet kvas or some other acidulent. Borsch is served with sour cream and pyrizhky or rye bread. There are many varieties of borsch depending on the locality, the ingredients used, and the season; these include sorrel borsch, spring borsch, cold borsch, and clear borsch (bouillon).

Long ago (pre-World War I), meat was not part of the everyday menu in Ukraine, with the exception of Sunday when poultry was the desired choice. Pork, 
beef, and lamb were saved for special occasions, feast, and weddings. Today through, there is no escaping the Ukrainian tendency to make meat the focal point of one's meals. There is an extensive list of poultry and fish dishes, many of which are old family recipes that may entice and inspire not only home cooks, but culinary savants, cooking instructors, and restaurant chefs to trend safety and happily into unknown territories.

Meat is usually eaten on feast days, Sundays, or at family celebrations. The most popular meat is pork and its products, such as ham, sausage (kovbasa), blood sausage (kyshka), headcheese (saltseson), smoked bacon, and salt pork. Meat is often ground to make patties (sichenyky), or is boiled or fried and served with potatoes, cabbage, buckwheat grits, or mushrooms. Sometimes it is stuffed. Veal is rarely served. In southern Ukraine lamb is popular. Neither raw meat nor horse meat is consumed. A lot of poultry is used, particularly chicken, baked in sour cream, stuffed, roasted, fried, or cooked for soup. Fish is fried, poached, or baked with stuffing. Jellied fish is popular, and fish stock is used in making borsch or soup. Cold appetizers are made from salted herring. Fish is one of the basic dishes of the Christmas supper.

Foods prepared with milk, dairy products, and eggs have long been a part of Ukrainian cooking. Gruels, noodles, little dumplings (shchypantsi), and zatyrka are boiled in milk. Soured milk is a favorite drink throughout Ukraine; a variant of this is huslianka or riazhanka, made by souring boiled milk with sour cream. Cottage cheese is eaten mixed with sour cream, as a filling in varenyky and pyrizhky, or with noodles, dumplings, potatoes, and kasha. It is also used in baking cheesecake. A salty cheese from sheep's milk known as budz or bryndzia is making in the Hutsul region and Bukovyna.

Fruits and berries, when in season, are eaten fresh or made into thickened purees (kysil, kholodets) and compotes. Some fruits are prepared for winter by drying or preserving. The most popular dishes made from either fresh or dried fruit are uzvar, compote, and kysil, a purée. Plum butter is made from plums; apples are preserved.

Salt pork, sunflower, flax, and hemp oils, and butter are the common cooking fats. Local herbs such as chives, thyme, celery leaves, garlic, dill, caraway seeds, and parsley, and imported spices such as pepper, cinnamon, bayleaves, and cloves, are used for seasoning.

Bread kvas (or syrivets), fruit or dill-pickle brine, and birch sap (in the spring) are popular folk beverages in Ukraine. Tea is the most widely consumed hot beverage, followed by coffee and cocoa. Alcoholic beverages such as mead, wine, fruit liqueurs (nalyvka), herb-flavored alcohol (zapikanka), alcohol with pepper (horilka z pertsem), and beer have been popular for many centuries.

Around 85 percent of Ukrainians are Christian. Therefore, the most important holiday in the Ukrainian church is Easter, followed by Christmas. Both holidays are celebrated according to the old-style Julian calendar, resulting in Christmas Day falling on January 7. Christmas Eve is called the Sviaty Vechir (Holy Evening). To celebrate, a ritual meal is 
traditionally prepared with 12 mostly meatless dishes, which symbolize the 12 apostles who gathered at the Last Supper. In some homes, the supper table is scattered with some hay, in memory of baby Jesus in the manger, with an elaborate tablecloth. Kolach is traditional bread placed in the middle of the table. The meal usually begins with a small bowl of kutya, a mixture of cooked wheat, honey, poppy seeds, chopped nuts, and apples. This is followed by several fish dishes, mushrooms, holubtsi (stuffed cabbage), varenyky (dumplings), fruits, cakes, such as makiwnyk (poppy seed cake) and bread. Borshch (a hearty soup) is usually included as well.

So, special dishes that are prepared for such feasts as Christmas Eve supper, Christmas, Easter, church holidays, and wakes differ from everyday foods. The Christmas Eve supper is rich in meatless dishes. On Christmas Day, New Year's Day, and Epiphany, however, roasts, fried sausages, cabbage rolls, jellied meats (studenets), and borsch are served. On Easter morning, after the liturgy and the blessing of the paska and other staples, everyone returns home to feast on the eggs, cold meats, and other foods that were blessed at church. On church holidays and at weddings relatives and guests are treated to an abundance of local delicacies. The kalach is prominent at burials and wakes. Kolyvo, a dish dating from pagan times and consisting of boiled wheat or barley with honey, is inseparable from the burial rites. It symbolizes the resurrection of the dead: just as the kernels of wheat must be buried to produce new plants, so the corpse of the dead person must be interred to be resurrected.

There are significant regional variations in Ukrainian cuisine that resulted from the availability of different agricultural products, foreign influences, or even the conservatism of the common people in regard to change. Not only is there a distinctive Poltava, Galician, or Kyiv borsch, but there are whole regional cuisines in Bukovyna, Transcarpathia, Volhynia, Dnieper region, and Slobidska Ukraine. Relatively little change in the nature of the local diet took place among the mountain peoples and in Polisia. The diet there is also poorer than in other regions. Today regional differences in the diet are disappearing under the influence of popular culinary literature; courses in cooking that, since the turn of the century, have been a port of public education in the countryside, particularly in Western Ukraine; and, most important, of semiprepared and prepared foods produced by the food industry. The food consumed by different socioeconomic classes differs in nutritional value and caloric content. The foods described above were characteristic of the middle classes and to some extent of the well-to-do peasants. The diet of the majority of Ukrainian peasants and workers, however, was of a lower standard. In Ukraine today most clerical workers, students, and factory workers lunch in cafeterias and restaurants, where the food is now standardized.

Ukrainian cooking has been influenced by Turkish and Tatar, Russian, Polish, Hungarian, and Romanian-Moldavian cooking. At the same time Ukrainian foods, particularly borsch, varenyky, and holubtsi, have become popular among Ukraine's neighbors. 
All these tremendous biodiversities, influences of different national cultures as well as the unique local culinary traditions of different regions formed the basis of the Ukrainian cuisine. Finally, it took shape during the 18-19 century along with the establishing of the Ukrainian literary language and the Ukrainian nation as such. In the early 20th century we had a very interesting and diverse gastronomic culture that was almost completely lost while the 70 years staying of Ukraine within the USSR. The unification and simplification led to the loss of the traditional Ukrainian cuisine techniques and recipes. Now we have to rummage for the old cookbooks, go to the research expeditions, reacquaint with local products to preserve what was destroyed, and leaning upon the traditions, give the start to the modern Ukrainian cuisine. The one Ukrainian cuisine that is worthy to show not only to Ukrainians but to the world as well.

On the initiative of Kyiv National University of Trade and Economics, (with multiple years of experience in training for professionals of the restaurant sector), and the support of the public organizations, institutions of restaurants and hospitality sector businesses, specialized educational institutions of Ukraine has established in September 2015 the public association «Ukrainian Culinary Union». The main purpose is, to unite efforts for the development of national cuisine, implementation of global standards of culinary art, enhancing professional skills of hospitality industry specialists. Ukrainian Culinary Union unite all interests and activitys in the field of the Hospitality Industry, Restaurant business/ educators and tutoring on implementing modern technologies and to set international standards for the professional development and mastering skills of food engineers, cooks \& chefs, confectioners and as well to promote the Ukrainian cuisine.

The team of the Ukrainian Culinary Union annually takes an active part in culinary festivals and competitions as well as organizes different culinary events in Ukraine. Over the past 5 years, members of the Ukrainian Culinary Union had participated in more than 30 international culinary competitions in Croatia, Macedonia, Greece, Germany, Turkey, Montenegro, Romania, Albania, Poland and Belarus and were able to win over 300 gold, silver and bronze medals. The brand of the Ukrainian Culinary Union is the BestCookFest International Culinary Festival, which is held annually not only in Kyiv, but also in other cities of Ukraine and the other countries of the world.

Due to its powerful potential the Ukrainian Culinary Union had provided an opportunity to organize 12 International Culinary Festivals «BESTCookFEST» in Kyiv, Kharkiv, Chernivtsi, Kamenetsk-Podolskiy, Izmir since 2015th, which was attended by representatives of various regions of the Ukraine and Chef teams from Poland, Belarus, Serbia, Croatia, Israel, Romania, Korea, Mongolia, Bulgaria, Azerbaijan and Turkey. Members of Ukrainian Culinary Union are continue their international activities and represent Ukrainian cuisine around the globe. They arrange cooperations with other recognized foreign national ches associations and educational institutions. 
Conclusions. Ukraine is an overwhelmingly agricultural nation and given its strategic location, it was plundered and fought over for centuries. Numerous bloody wars were fought over the fertile Ukrainian soil, tearing the country and its culture to pieces. Ukraine's culinary history reflects this turbulent history and the blended heritage of its people is vibrant. During the course of history, Ukrainians gallantly fought off some raids with success, but at the same time accepted and adopted some of their invaders rather strange and unusual cooking habits, techniques, tastes, and styles, while vehemently rejecting others.

Because of its storied history and great variety, Ukrainian food can be enjoyed by all who have an opportunity to become acquainted with it. Ancient Ukrainian recipes, at first, are the resource for how to make a wide selection of well-balanced, healthy Ukrainian dishes, and the second, they are interesting assembly of illuminating insights into Ukrainian culture and society.

While Ukrainian food has suffered from some negative stereotypes in the past, this lovely patchwork culinary tradition is finally being rediscovered as a national cuisine with wholesome appeal and gastronomic zing. Ukrainian culinary authentically is a wonderful tale that reflects two very basic Ukrainian values: hospitality and community spirit. Even in the hardest times, past and present, the spirit of hospitality always remains. The best food is always for the guests, as is the best rooms and the best linen.

Every year new restaurants is opened in Ukraine and instead of flirting with the stereotypes about Ukrainian cuisine it began to explore the authentic recipes, apply the latest technologies and create something completely new, the modern gastronomy. Every day we explore the peculiarities of the new local products, travel to farms and make discoveries. The quintessence of our work turns into tasting sets of the new Ukrainian cuisine. And now the Ukrainian cuisine is no longer associated only with «salo (lard), borsch and varenyky» and people are ready to accept the fact that Ukrainian cuisine can be really impressive.

Now when there is a difficult struggle to preserve our national identity, the awareness of our own cuisine as part of the common cultural code is crucially important. Therein we see our mission for which we are ready to work seven days a week. The acquaintance of Ukrainians with our own culture and the introduction of this culture to the world - by surprises, aesthetic pleasures and gastronomical experiences - that's what Ukrainian Culinary Union team work on.

\section{REFERENCES}

1. Albemas, N. V. (2011). Ukrainska kukhnia. Naismachnishi stravy na sviatkovomu stoli [Ukrainian cuisine. The most delicious dishes on the holiday table]. Donetsk, Ukraine: BAO (in Ukrainian).

2. Artiukh, L. F. (1977). Ukrainska narodna kulinariia: istoryko-etnohrafichne doslidzhennia [Ukrainian folk cooking: historical and ethnographic research]. Kyiv, Ukraine: Naukova dumka (in Ukrainian). 
3. Dotsiak, V. S. (1998). Ukrainska kukhnia [Ukrainian cuisine] (2nd ed.). Lviv, Ukraine: Oriiana-Nova (in Ukrainian).

4. Dubovis, H. O. (2006). Ukrainska kukhnia: povne zvedennia retseptiv natsionalnoi kukhni XVIII-XXI st. [Ukrainian cuisine, a complete compilation of recipes cuisine XVIII-XIX centuries. ]. Kharkiv, Ukraine: Folio (in Ukrainian).

5. Bezusenko, L. M. (Ed.). (2005). Entsyklopediia ukrainskoi kukhni [Encyclopedia of Ukrainian cuisine]. Donetsk, Ukraine: Stalker (in Ukrainian).

6. Shalyminov, O. V. (et al.). (2000). Zbirnyk retseptur natsionalnykh strav ta kulinarnykh vyrobiv: dlia pidpryiemstv hromadskoho kharchuvannia vsikh form vlasnosti [Collection of recipes of national dishes and culinary products, catering for all types of property]. Kyiv, Ukraine: A. S. K. (in Ukrainian).

7. Karpenko, Iu. M. (2013). Ukrainska kukhnia: krashchi stravy [Ukrainian cuisine: the best dishes]. Donetsk, Ukraine: Hloriia Treid (in Ukrainian).

8. Kylymnyk, S. (1994). Ukrainskyi rik u narodnykh zvychaiakh $\mathrm{v}$ istorychnomu osvitlenni [Ukrainian Year in folk customs in a historical light] (Vol. 1). Kyiv, Ukraine: Oberehy (in Ukrainian).

9. Kylymnyk, S. (1994). Ukrainskyi rik u narodnykh zvychaiakh v istorychnomu osvitlenni [Ukrainian Year in folk customs in a historical light] (Vol. 2). Kyiv, Ukraine: Oberehy (in Ukrainian).

10. Kyrchiv, R. F. (1978). Etnohrafichne doslidzhennia Boikivshchyny [Ethnographic research Boikivshchyna]. Kyiv, Ukraine: Naukova dumka (in Ukrainian).

11. Kyrchiv, R. F. (2002). Iz folklornykh rehioniv Ukrainy: narysy i statti [From folklore regions of Ukraine: Essays and Articles], Pavliuk, S. (Ed. ). Lviv, Ukraine: n. p.

12. Mazaraki, A. A., Peresichnyj, M. I., \& Fel'dman, I. A. (2012). Znamenitye ukrainskie bljuda [Famous Ukrainian dishes]. Kyiv, Ukraine: Gubernikov (in Russian).

13. Miroshnychenko, S. A. (2013). Domashnia ukrainska kukhnia [Home Ukrainian cuisine]. Donetsk, Ukraine: BAO (in Ukrainian).

14. Pavliuk, S. P. (1991). Tradytsiine khliborobstvo Ukrainy: ahrotekhnichnyi aspekt [Traditional farming Ukraine: Agrotechnical aspect]. Kyiv, Ukraine: Naukova dumka (in Ukrainian).

15. Polonska-Vasylenko, N. (1993). Istoriia Ukrainy. Vid seredyny XVII stolittia do 1923 roku [History of Ukraine. From the middle of the XVII century until 1923] (Vol. 2). Kyiv, Ukraine: Lybid (in Ukrainian).

16. Polonska-Vasylenko, N. (1993). Istoriia Ukrainy. Do seredyny XVII stolittia [History of Ukraine. By the middle of XVII century] (Vol. 1). Kyiv, Ukraine: Lybid (in Ukrainian).

17. Zdobnov, A. I., Cyganenko, V. A., \& Peresichnyj, M. I. (1998). Sbornik receptur bljud i kulinarnyh izdelij: dlja predprijatij obshhestvennogo pitanija [Collection of recipes of dishes and culinary products: for catering]. Kyiv, Ukraine: A. S. K. (in Russian). 